\title{
First finding of Prozercon bulgariensis Ujvári, 2013 (Acari, Zerconidae) from Turkey
}

\author{
Rasit Urhan (Corresponding author) \\ Department of Biology, Faculty of Arts \& Sciences, Pamukkale University, Denizli, Turkey \\ E-mail: rurhan@pau.edu.tr \\ Mehmet Karaca \\ Program of Biomedical Device Technology, Department of Electronic and Automation, Denizli \\ Vocational School of Technical Sciences, Pamukkale University, Denizli, Turkey \\ E-mail: karacamehmet @ pau.edu.tr
}

\begin{abstract}
During systematic studies on zerconid mites in Coastal Aegean Section of Turkey, species belonging to genus Prozercon were examined. Among them, Prozercon bulgariensis was recorded for the first time from Turkey. Descriptions, measurements, drawings of female, male and deutonymph specimens of $P$. bulgariensis were given based on collected materials from Datça and Marmaris counties of Muğla province.
\end{abstract}

Keywords: Acari, Prozercon bulgariensis, systematic, new record, Coastal Aegean Section, Turkey

DOI: $10.7176 / J S T R / 6-07-10$

\section{Introduction}

Zerconids are one of the mite families of order Mesostigmata (Acari) in Holarctic region. These small mites are oligophagous predators and their distribution confined to Northern Hemisphere (Karaca, 2019). Systematically, this family is a well studied group in many Europe countries and Turkey. So far, 46 genera and over 400 species have been identified Kaczmarek et al., 2020). In Turkey, 118 species belonging to 2 genera (Prozercon and Zercon) are known (Urhan and Karaca, 2019; Urhan et al., 2020). According to knowledge based on recent studies, Prozercon Sellnick, 1943 is the second most crowded genus of the family Zerconidae both in Turkey and the world (Ujvári, 2011; Urhan et al., 2019a-b). Until today, 36 Prozercon species have been recorded from Turkey (Urhan et al., 2020). In the present study, first occurrence of Prozercon bulgariensis was given from Turkey based on collected materials from Datça and Marmaris counties of Muğla province.

\section{Materials and Methods}

Different materials (litter, soil and moss samples) including mites were collected from Coastal Aegean Section of Turkey. GPS information of collected materials were taken by Garmin GPSmap 62s during field studies. Collected materials were transferred to acarology laboratory and were placed in Berlese funnels. According to their humidity of samples, they were kept for about 5-7 days in these funnels for extracting mites. Then, ethanol bottles including extracted mites were taken to Petri dishes for examination of zerconid mites. After that, zerconids were selected and separated by using a stereo microscope (Nikon SMZ745T). Finally, collected zerconids were taken in $60 \%$ lactic acid for their identification. During examinations of zerconid specimens, following terminologies were used; Sellnick (1958), Halašková (1969), Błaszak (1974), Mašan \& Fend'a (2004). Illustrations of zerconid specimens were done by using a light microscope (Olympus CX41) with DP25 camera. All examined specimens were taken in $70 \%$ ethanol and stored in Acarology Laboratory of Pamukkale University, Denizli (Turkey).

All measurements of different body parts and dorsal setae were presented as micrometers $(\mu \mathrm{m})$.

\section{Results}

After examinations of different collected materials from Coastal Aegean Section of Turkey, 71 female, 13 male and 6 deutonymph specimens of Prozercon bulgariensis Ujvári, 2013 were recorded from Datça

91 | $P$ a g e

www.iiste.org 
and Marmaris counties of Muğla province. Descriptions, measurements of idiosoma and different dorsal setae of identified specimens were given.

Family Zerconidae Canestrini, 1891

Genus Prozercon Sellnick, 1943

Type species: Zercon fimbriatus C. L. Koch, 1836

Posterior parts of peritremal shields extending to setae R5-R6. Peritremal shields with 2 types of setae: $p 1$ short, smooth or finely plumose, $p 2$ short and smooth. There is no gap between peritremal shield and the edge of the podonotum. Adgenital shields and glands $g v 2$ absent. Opisthonotum with 7 or 8 pairs marginal setae. Anterior margin of ventrianal shield always with 1 pair of setae (Karaca et al., 2017).

Prozercon bulgariensis Ujvári, 2013 (Figures 1-2)

Materials examined. Details of collected materials for P. bulgariensis specimens in this study were presented below.

Datça county (Muğla province): Marmaris-Datça highway, closer to Gulf of Doris, N $36^{\circ} 47.079^{\prime}$, E $28^{\circ}$ 02.007 ', 42 m a.s.1., 21.01.2019, moss, 5 우오. Marmaris-Datça highway, closer to Gulf of Doris, $\mathrm{N} 36^{\circ}$ 46.483 ', E $27^{\circ} 59.725^{\prime}$, $264 \mathrm{~m}$ a.s.l., 21.01.2019, moss, 1 ㅇ. Marmaris-Datça highway, Balıkaşıran strait, $\mathrm{N} 36^{\circ} 46.511$ ', E $27^{\circ} 59.235$ ', $350 \mathrm{~m}$ a.s.1., 21.01.2019, litter, soil and moss samples under kermes oak (Quercus coccifera) and rockrose (Cistus sp.), 19웅, $3 \hat{0} \hat{0}, 3$ deutonymphs.

Marmaris county (Muğla province): Muğla-Marmaris highway, closer to Beldibi district, N 36 54.947 ', E $28^{\circ} 16.777$ ', 119 m a.s.l., 21.01.2019, litter, soil and moss samples under Turkish pine (Pinus brutia), rockrose (Cistus sp.), sage (Salvia sp.) and holly oak (Quercus ilex), 39웅, 9 $\hat{0} \hat{0}, 3$ deutonymphs. Marmaris-Datça highway, closer to Armutalan district, N $36^{\circ} 51.614^{\prime}$ ', E $28^{\circ} 14.344^{\prime}$ ', 83 m a.s.l., 21.01.2019, litter, soil and moss samples under holly oak (Quercus ilex) and kermes oak (Quercus coccifera), 7 우우, $10^{\Uparrow}$.

Female (Figure 1)

Dorsal side. Length (without gnathosoma) and width ranges in 10 specimens 344-366 and 246-270, respectively. Ornamentation of idiosomal shields were illustrated in Figure 1. Dorsal cavities are uniform, in equal size, saddle-like and weakly sclerotised.

Dorsal setae (Figure 1). Podonotum with 20 pairs of setae. Number of setae in $j$ series with 6 pairs, $z$ series with 2 pairs, $s$ series with 5 pairs and $r$ series with 7 pairs. Setae $j 1, z 2, s 5$ and all marginal $r$ setae slightly elongated and plumose. Remaining setae of podonotum short, smooth and needle-like. Podonotal shield covered with reticulate pattern. Opisthonotum with 22 pairs of setae. Number of setae in $J$ series with 6 pairs, $Z$ series with 5 pairs, $S$ series with 4 pairs and $R$ series with 7 pairs. Except $R 2-7$ setae, all opisthonotal setae plumose. Setae $J 2-5$ reach to base of following setae in related series. None of setae in $Z$ series reach to base of following setae in related series. Seta $Z 4$ reach to posterior margin of opisthonotum. Except seta $S 1$, all setae in $S$ series reach to beyond of opisthonotum. The interval between setae $J 6$ and $J 6$ is $68-73$. The interval between setae $J 6$ and $Z 5$ is $30-35$. Unlike other setae in $R$ series, seta $R 1$ plumose. Opisthonotal shield covered with relatively large alveolar pits.

Glands (Figure 1). Three pairs of pores present on podonotum: pore pol located closer to insertion of seta $s 1, p o 2$ located on the line connecting setae $j 4$ and $s 3$ (closer to $s 3$ ), po3 located on the line connecting setae $s 4$ and $z 2$ (closer to $s 4$ ). Four pairs of pores present on opisthonotum: pore Pol located closer to insertion of seta Z1,Po2 located on the line connecting setae $Z 1$ and $Z 3$ (closer to ZI), Po3 located on the line connecting setae $J 4$ and $Z 3$ (closer to Z3), Po4 located on the line connecting setae Z4 and Z5 (closer to Z5). 


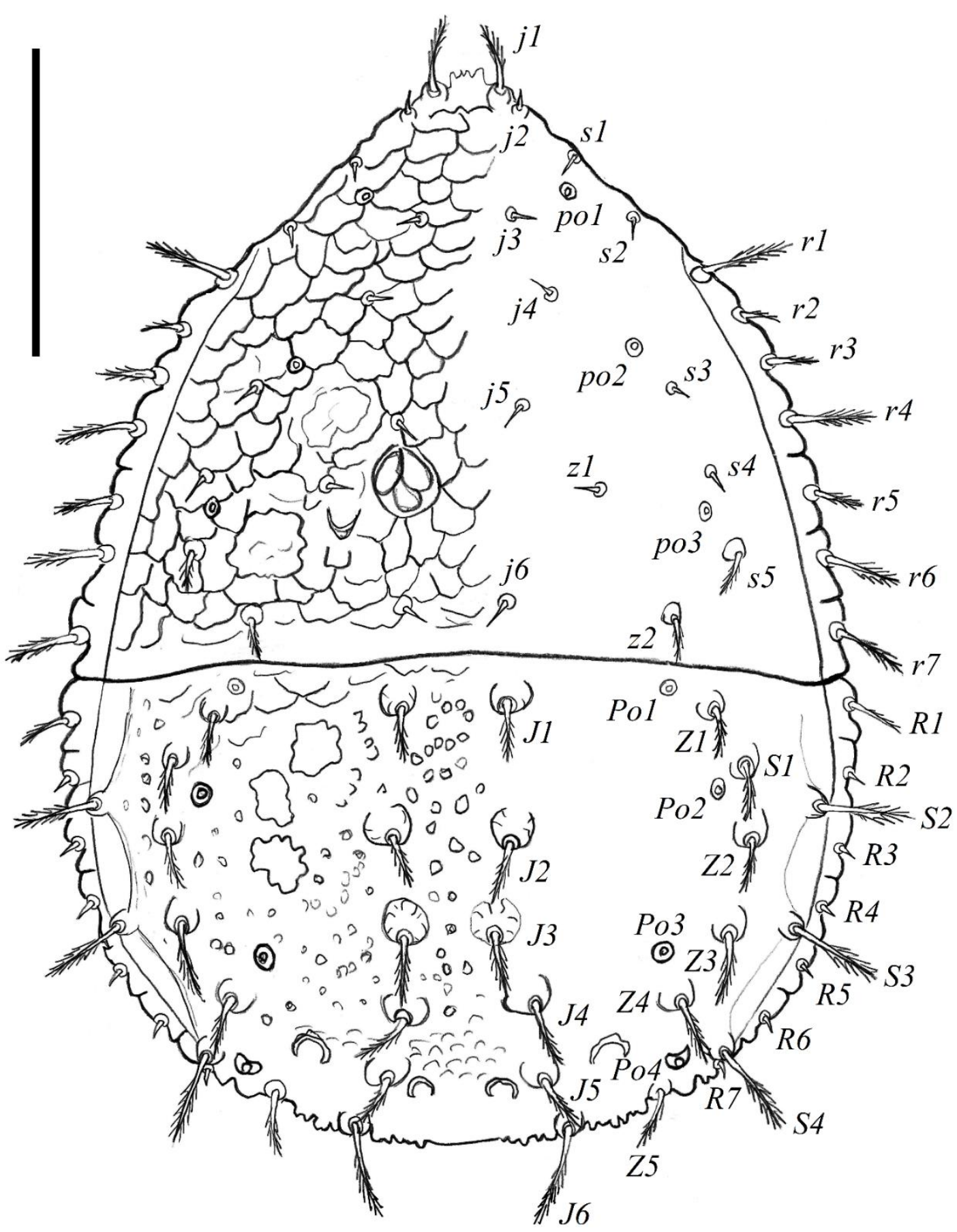

Figure 1. Dorsal view of Prozercon bulgariensis (female). Scale bar equal to $100 \mu \mathrm{m}$.

Ventral side. Posterolateral tips of peritrematal shield reach to level of setae R2-3. Chaetotaxy and ornamentation of the peritrematal shield are characteristical for Prozercon species. Peritrematal shield with 2 pairs of setae ( $p 1$ and $p 2$ ), both of them short, smooth and needle-like. Peritremes twisted anteriorly, and glands $g v l$ located closer to anterior parts of peritremes. Glands $g v 2$ absent between posterior part of genital shield and anterior part of ventrianal shield.

Anterior margin of ventrianal shield with 2 setae. Glands $g v 3$ located closer to insertion of adanal setae. Anterior and lateral parts of ventrianal shield covered with squamous pattern.

Male (Figure 2A)

Length (without gnathosoma) and width ranges in 10 specimens 280-296 and 201-213, respectively. Ornamentation of idiosomal shields were illustrated in Figure 2A. The interval between setae $J 6$ and $J 6$ 
is 65-68. The interval between setae $J 6$ and $Z 5$ is $20-33$. Dorsal side, ventral side, sculpture of podonotum and opisthonotum, shape of dorsal cavities basically similar to that of female.
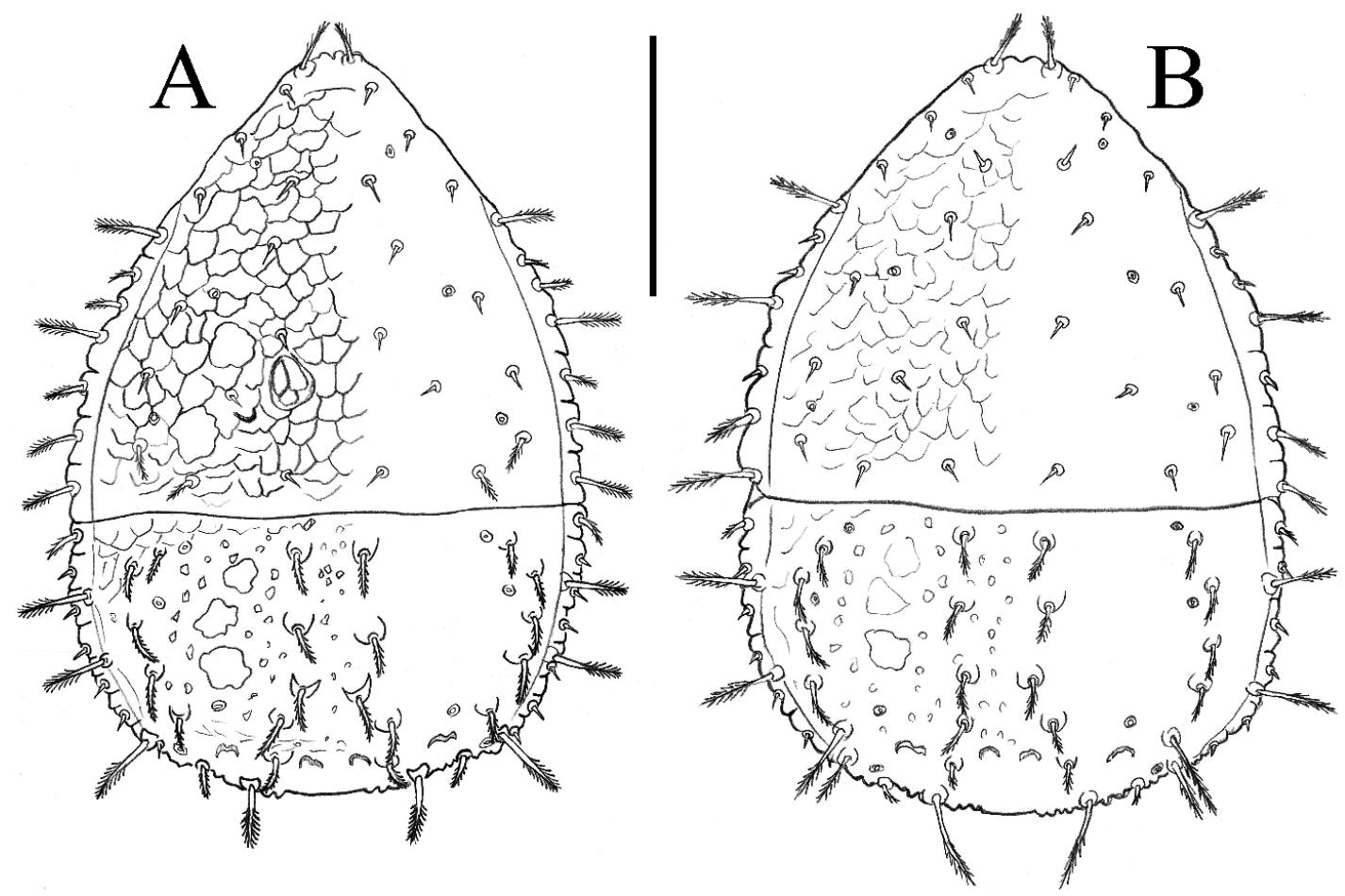

Figure 2. Dorsal views of Prozercon bulgariensis specimens: A) Male, B) Deutonymph. Scale bar equal to $100 \mu \mathrm{m}$.

Deutonymph (Figure 2B)

Length (without gnathosoma) and width ranges in 6 specimens 283-301 and 206-219, respectively. Ornamentation of idiosomal shields were illustrated in Figure 2B. The interval between setae J6 and J6 is 59-64. The interval between setae $J 6$ and $Z 5$ is 20-25. Dorsal side, ventral side, sculpture of podonotum and opisthonotum, shape of dorsal cavities basically similar to that of female, except some difference of dorsal setae. Although setae Z2, S5, R2-3 and $R 5$ plumose in female and male specimens, all of these setae are short, smooth and needle-like in deutonymph specimens. Also, none of setae in $J, Z$ and $S$ series on opisthonotum reach to base of following setae in related series. In contrary of female and male specimens, seta $Z 4$ reach to beyond of opisthonotum in deutonymphs.

Length ranges of opisthonotal setae and distances between setae within longitudinal rows for female, male and deutonymph specimens: see Table 1. 
Table 1. Measuring ranges of opisthonotal setae and distances between their bases in $J, Z$, and $S$ rows of Prozercon bulgariensis (Abbreviations: F: female, M: male, DN: deutonymph).

\begin{tabular}{|c|c|c|c|c|c|c|c|c|c|c|c|}
\hline Setae & $\mathbf{F}$ & $\mathbf{M}$ & DN & Setae & $\mathbf{F}$ & $\mathbf{M}$ & DN & Setae & $\mathbf{F}$ & $\mathbf{M}$ & DN \\
\hline$J 1$ & $22-30$ & $13-25$ & $10-15$ & $Z 1$ & $18-24$ & $12-22$ & $14-15$ & $S 1$ & $21-22$ & $15-28$ & $17-23$ \\
\hline$J 1-J 2$ & $42-45$ & $27-43$ & $31-32$ & $\begin{array}{c}\mathrm{Z1}- \\
\mathrm{Z2}\end{array}$ & $42-43$ & $28-32$ & $34-38$ & $\begin{array}{c}S 1- \\
S 2\end{array}$ & $26-29$ & $21-23$ & $16-17$ \\
\hline$J 2$ & $30-32$ & $13-28$ & $15-16$ & $Z 2$ & $18-20$ & $12-22$ & $14-18$ & $S 2$ & $32-35$ & $29-35$ & $32-34$ \\
\hline$J 2-J 3$ & $35-36$ & $25-38$ & $26-27$ & $\begin{array}{c}\text { Z2- } \\
\text { Z3 }\end{array}$ & $29-31$ & $23-28$ & $20-23$ & $\begin{array}{l}\text { S2- } \\
\text { S3 }\end{array}$ & $41-43$ & $27-40$ & $38-44$ \\
\hline$J 3$ & $26-31$ & $13-31$ & $15-17$ & $Z 3$ & $25-26$ & $16-24$ & $16-21$ & $S 3$ & $31-32$ & $27-33$ & $34-36$ \\
\hline J3-J4 & $26-27$ & $18-28$ & $15-16$ & $\begin{array}{c}\text { Z3- } \\
\text { Z4 }\end{array}$ & $32-35$ & $20-29$ & $21-28$ & $\begin{array}{l}\text { S3- } \\
\text { S4 }\end{array}$ & $41-50$ & $34-45$ & $34-40$ \\
\hline$J 4$ & $18-22$ & $12-22$ & $14-16$ & $Z 4$ & $20-21$ & $12-14$ & $34-37$ & $S 4$ & $30-33$ & $28-31$ & $33-34$ \\
\hline J4-J5 & $23-25$ & $16-24$ & $15-16$ & $\begin{array}{c}Z 4- \\
Z 5\end{array}$ & $31-33$ & $21-32$ & $25-27$ & & & & \\
\hline$J 5$ & $17-19$ & $10-18$ & $13-14$ & $Z 5$ & $15-18$ & $9-17$ & 8-9 & & & & \\
\hline J5-J6 & $14-18$ & $12-16$ & $17-18$ & & & & & & & & \\
\hline$J 6$ & $24-30$ & $22-30$ & $32-34$ & & & & & & & & \\
\hline
\end{tabular}

\section{Discussion and Conclusion}

Prozercon bulgariensis was described as a new species from several provinces of Bulgaria in 2013. Ujvári reported this species mainly from moss habitats (Ujvári, 2013). Up to now, there is no distribution records from other countries, except its terra typica (Bulgaria). Based on collected materials from Datça and Marmaris provinces of Muğla province, specimens of $P$. bulgariensis were found for the first time in Turkey. Thus, spreading area of this species expanded in Mediterranean region (Figure 3). So, new records of $P$. bulgariensis may occur from Greece coasts and some Aegean islands in the future. 


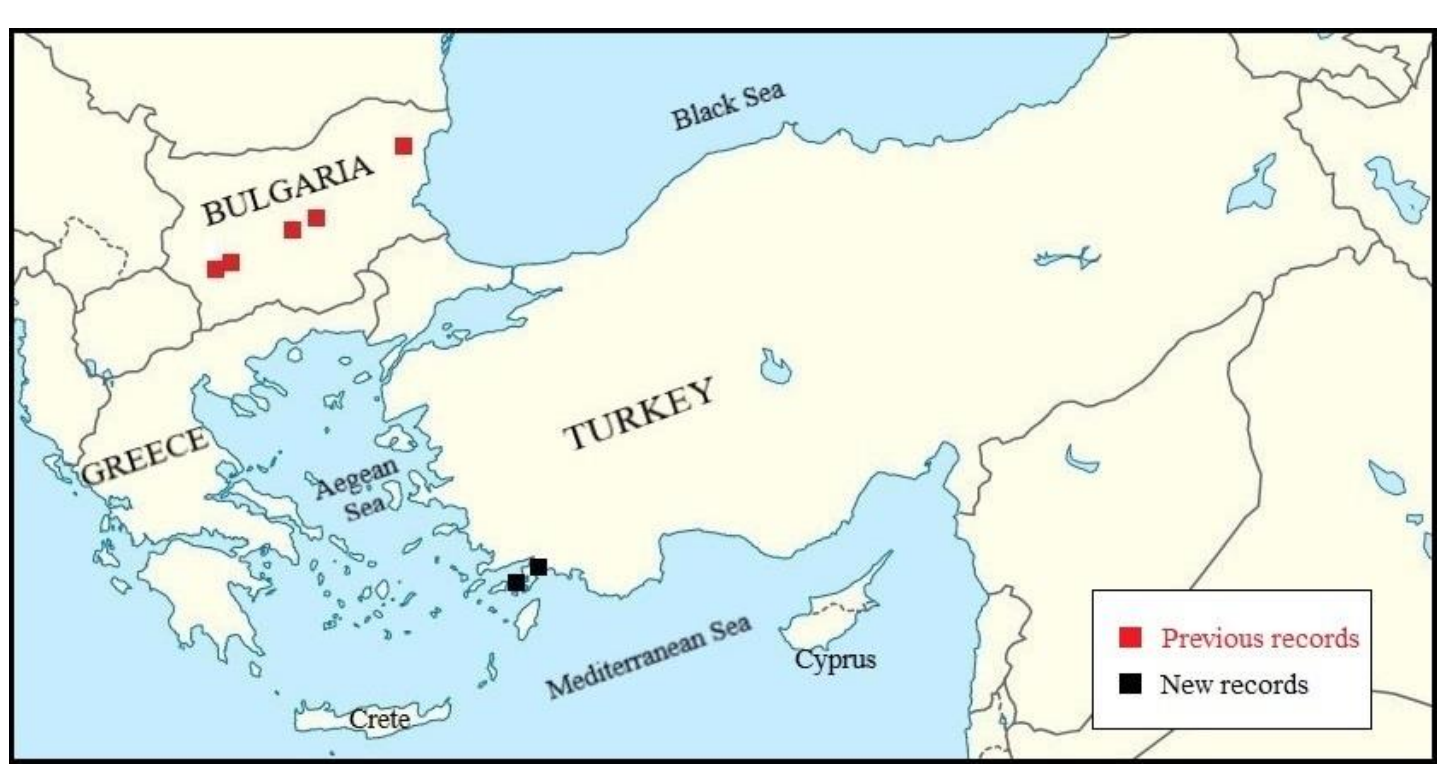

Figure 3. Known distribution of Prozercon bulgariensis (map not to scale).

On the other hand, setal and morphological characters of Turkish specimens very similar to those of type specimens. According to comparison of length and width intervals between Bulgarian and Turkish specimens (Table 2), these measurements are approximately the same size. However, although some specimens (both Bulgarian and Turkish) show minor differences in terms of length and width, these are not remarkable.

With this new record for the Turkish acarofauna, number of recorded Prozercon species known from Turkey rised to 37 (Urhan et al., 2019a-b, 2020). Also, similar future studies will be done significant contribution to Turkish acarofauna.

\section{Acknowledgements}

This study was financially supported by TÜBİTAK (Scientific and Technological Research Council of Turkey), with $118 \mathrm{Z} 101$ project number.

Table 2. Length and width intervals of idiosoma of Prozercon bulgariensis between Turkish and Bulgarian specimens (Abbreviations: F: female, M: male, DN: deutonymph, PN: protonymph).

\begin{tabular}{|l|c|c|c|c|}
\hline & F & M & DN & PN \\
\hline Bulgarian & $345-355 \times 285-$ & $269-285 \times 215-$ & $237-296 \times 183-$ & $204-247 \times 161-$ \\
specimens & 295 & 231 & 247 & 188 \\
(Ujvári, 2013) & & $280-296 \times 201-$ & $283-301 \times 206-$ & - \\
\hline $\begin{array}{l}\text { Turkish specimens } \\
\text { (present study) }\end{array}$ & $\begin{array}{c}344-366 \times 246- \\
270\end{array}$ & 213 & 219 & - \\
\hline
\end{tabular}

\section{References}

Błaszak, C. (1974). Zerconidae (Acari, Mesostigmata) Polski. Monografie Fauny Polski, Poland: Warszawa, $315 \mathrm{pp}$.

Halašková, V. (1969). Zerconidae of Czechoslovakia (Acari: Mesostigmata). Acta Universitatis Carolinae-Biologica, 3-4: 175-352.

Kaczmarek, S., Marquardt, T., Jangazieva, B. (2020). Zercon utemisovi sp. n. - a new species of Zerconidae (Parasitiformes, Mesostigmata) from Kazakhstan with notes on Zercon karadaghiensis Balan, 1992. International Journal of Acarology, 46: 52-59.

Karaca, M. (2019). Zercon kadiri sp. n., a new oligophagous mite from Eastern Anatolia (Acari: Mesostigmata: Zerconidae). Zoology in the Middle East, 65: 261-267. 
Karaca, M., Ordoukhanian, C., Ahadiyat, A., Urhan, R. (2017). New occurrences of zerconid mites (Acari: Zerconidae) from Iran, with checklist and a key to the Iranian species. International Journal of Acarology, 43: 603-611.

Mašán, P., Fend'a, P. (2004). Zerconid mites of Slovakia (Acari, Mesostigmata, Zerconidae). Slovak Academy of Sciences, Institute of Zoology Bratislava, 238 pp.

Sellnick, M. (1958). Die familie Zerconidae Berlese. Acta Zoologica Academiae Scientiarum Hungaricae, 3: 313-368.

Urhan, R., Karaca, M., Duran, E.H. (2020). Description of Prozercon miraci sp. nov. (Acari: Mesostigmata: Zerconidae) from Coastal Aegean Section in Turkey, with a key to the Turkish species. Acarological Studies, 2: 18-23.

Ujvári, Z. (2011). Six new species of Prozercon Sellnick, 1943 (Acari, Mesostigmata, Zerconidae) from Greece, with remarks on the genus. Zootaxa, 2785: 1-31.

Ujvári, Z. (2013). Two new species of Prozercon Sellnick, 1943 (Acari, Mesostigmata, Zerconidae) from Bulgaria. International Journal of Acarology, 39: 263-271.

Urhan, R., Karaca, M. (2019). A new species of the genus Zercon (Acari, Mesostigmata, Zerconidae) from Kastamonu, Turkey. Acarological Studies, 1: 3-10.

Urhan, R., Duran, E.H., Karaca, M. (2019a). Prozercon sellnicki Halašková, 1963: A new record of zerconid mites (Acari, Zerconidae) for the Turkish fauna. International Journal of Scientific and Technological Research, 5: 260-264.

Urhan, R., Karaca, M., Duran, E.H., Aksu, B., Bilki, K. (2019b). A new record of the family Zerconidae (Acari: Mesostigmata) from Turkey: Prozercon rekaae Ujvári, 2008. 5th International Conference on Engineering and Natural Science, p. 100-104, Prague (Czech Republic), 12-16 June.

Urhan, R., Karaca, M., Duran, E.H. (2020). Description of Prozercon miraci sp. nov. (Acari: Mesostigmata: Zerconidae) from Coastal Aegean Section in Turkey, with a key to the Turkish species. Acarological Studies, 2: 18-23. 